\title{
Men Reflecting on Prevention of Conjugal Violence Approach
}

\author{
Adelma do Socorro Gonçalves Pimentel \\ Graduate Program in Psychology, Federal University of Pará, Pará, Brazil \\ Email: adelmapi@ufpa.br
}

Received 21 August 2015; accepted 20 November 2015; published 23 November 2015

Copyright (C 2015 by author and Scientific Research Publishing Inc.

This work is licensed under the Creative Commons Attribution International License (CC BY). http://creativecommons.org/licenses/by/4.0/

(c) (i) Open Access

\section{Abstract}

The theme is part of a field of study on gender, health and violence; it narrates the perspectives of military policemen on domestic violence and the forms of prevention suggested to both men and women. As for the psychological point of view, the gestalt phenomenological clinic is the area of focus based on the area of human rights. We understand that conjugal violence provokes psychic and intersubjectivity suffering for the distortion it causes on how men make contacts and social adjustments, in other words, for the introjection of conceived male models. The subjects of research were college graduates between 19 and 30 years of age. We used a questionnaire with three integrated parts: 1) identification of informant and wife/partner; 2) experience with situations of violence; 3 ) prevention. This paper covers only the third part. The results show that the definitions of violence indicate disrespect, imposition and lack of emotional control. As for prevention, the suggestions made to the wives highlighted self-control and report to the police, that they are conscious of their emotions, and if they are unable to live in a healthy conjugal relationship, that they terminate their marriage/involvement. For the men, the suggestions focused mainly on equality of rights, to see women not as an object but to take good care of their wives/partners. As a conclusion, we have indicated brief psychotherapy and the group as an intervention for the psychological suffering originated from experience with violence, to welcome and listen to the men, woman and the couple, the depathologization, and the exam of nexus relations between genders, equality and power.

\section{Keywords}

Conjugal Violence, Qualitative Research, Psychic Suffering, Men

\section{Introduction}

The subject is part of a field of study on gender, health and violence of the graduate program in psychology of 
Universidade Federal do Pará (Federal University of Pará), and results from the exploratory collection of material for the project financed by FAPESPA, through Notice $08 / 2014^{1}$. The text narrates the point of view of men who are members of the police force on conjugal violence and the forms of prevention suggested by them for both men and women.

To accommodate the narrative of the participants we have distinguished our method of ratiocination. It is based on our guiding principles of research that aims to understand phenomenologically the experience, relation between subjective and inter subjective in the context where it takes place ${ }^{2}$, the forms how language participates in communication of and between the subjects; to position the conception of gender and violence (psychological and physical) within a dynamic-structural focus; delineate care in an anthological dimension, and locate its flux in health services in order to configure a network (Holanda, 2014; Moura, 1989; Ayres, 2004; Amatuzzi, 2001; Pimentel, 2003; Keen, 1979; Japiassu, 1982; Ricoeur, 1988; Connel, 1995).

Such fundaments permit to update the involvement of clinical psychology in the field of study of violence between couples reshaping a classic practice associated to a private model.

The clinical practice of psychologists and psychoanalysts has shown the importance of violence in the world today, and confirms that this phenomenon affects the human being in different ways: in its subjectivity and behavior, in its quality of life, family relations, education, political life, etc. From the political and philosophical point of view, it undermines the concept that it is defined as human and points to the "inhuman" in the other individual and in each one of us (Safra et al., 2009: p. 8).

As for the health care practices, an existential ontological approach concerns the three dimensions that operate in an integrated manner: self-care, care for the other, and care with the context. Together they permit that the psychotherapy interventions with the couple and the males articulate among themselves aiming "the assessment of the relation between purposes and means, and its practical sense for the patient, according to a dialogue as symmetric as possible between the professional and the patient” (Ayres, 2004: p. 86).

On the subject of clinical psychology, our approach tends to give the psychological and intersubjective suffering for the distortion on how the men make contacts and social adjustments, that is, directed by the introjection of the gestaltic point of view models a substantiation in the area of human rights; thus, our interventions understand that conjugal violence is an action that provokes males: "the media men... they become models for other men, with all the consequent frustrations resulting from an ideal type absolutely distant from the real life (Blay, 2014: p. 19). In turn, Gold \& Zahn (2014: p. 47) assure that devised norms when chronically introjected require a psychotherapy procedure of integration and awareness, because the subjects "when trying to get rid of thoughts or feelings, sometimes worsen the symptoms, by adding another layer of "should be" and self-criticism, and put aside the energy denied and little understood".

As for the concept of psychological suffering, it relates itself to studies on labor psychology ${ }^{3}$, however the authors have done distinct links with studies on gender trying to configure an extension between mental health ${ }^{4}$ and gender. For example, Albuquerque (2012: p. 15) points out that psychological suffering "is an uneasiness that expresses itself as anguish, concern, anxiety tension and/or discouragement not necessarily characterized as strict mental illness". Besides, the author mentions a group of researches that indicates greater prevalence of anxiety and depression among women, possibly by gender inequalities, and "by the fact that be men hardly ever discuss their health problems, unless considered serious” (p. 19).

Santos (2009), and Silva \& Cols (2013: p. 1) claim that, "The psychological suffering experience is constructed socially and brings among itself the conformation of values and norms of a certain society and historical era. It may be understood as something highly individual, as the experience of set of uneasiness in the subjective context."

Considering the complexity of the issues that surround us, we have examined that the decline in psychological and intersubjective suffering in men (and couples) requires the effectiveness of public policies such as the Brazilian Comprehensive Healthcare Policy for Men (PNAISH), the strengthening of basic healthcare services, and dialogue with both male and female movements that claim to end violence against women (Brasil, 2008; Figueiredo, McBritto, \& Peixoto, 2012).

In regard to violence, the general concept we have used, refers to the asymmetrical daily practices, in which

\footnotetext{
${ }^{1}$ Authorized by the Ethical Committee: Opinion: 893.044; 17/11/2014.

${ }^{2} \mathrm{~A}$ repositioning of the subject in his/her relation with the world (Holanda, 2014: p. 27).

${ }^{3}$ Dejours et al. (1994).

${ }^{4}$ According to psychiatric nosology, depression, anxiety, sleeping disorders, irritability are among the most common mental disorders (Albuquerque, 2012).
} 
some members of a social system are denied or invalidated as subjects installing the domination and inequality as vertical action and imposition of beliefs and values (Arendt, 1970/2014). In the gender dimension, we refer, among others, to a consideration by Beauvoir (1990: p. 16) about reciprocity and inequality, where philosophy has reassured,

"There are as many men as women on Earth, and both groups had been initially interdependent; they ignored each other or accepted the other party autonomy; it was a historical event that subordinated the weak to the strong: the Jewish diaspora, the introduction of slavery in America, the colonial conquests are precise facts.”

We added to the clinical intervention on the violence that occurs between couples, the understanding that the attitudes of each spouse during conjugal violence in their conflicting everyday life are dynamic, that is, they demand that psychologists refute essential thesis to understand what is violence, and its association to "passivity" and the "victim" role attributed to women; and, the "active" attitude rather than that of an "aggressor" inflicted on men. This way, they may reveal some games of domination established between themselves, and overcome the use some already of saturated categories such as: women "fragility", men "strength", victim, aggressor "attached" to the subjects in a timeless way.

Back to the specificities of the research, within the context of health, the Núcleo de Pesquisas Fenomenológicas - NUFEN (Nucleus of Phenomenological Research) and the Instituto de Estudos Superiores (Institute of Higher Education) for the military educational training and intervention directed by the gestalt clinical psychology, in order to offer the men and the couples, between 19 and 50 years of age, a space of brief psychotherapy ${ }^{5}$. The interlocutors were men attending the first year at Institute of.

Higher Studies for Military Educational Training ${ }^{6}$ aiming the execution of planning in the various units of public safety in the state. We observed that the profession is one of the dimensions that form the processes of subjectivation, even though our analysis of the responses were done considering the respondents' apprehension on men's social representation; thus, we integrated such aspects to the meanings attributed to the horizon of experience by the participants without reducing their experience to the world of military institution.

We emphasize that in the State of Pará, justice and health are areas where projects of attention to men have been implemented. At the State Health Secretariat a working plan has been implemented by the Men's Health Coordination and regulated by Ordinance 2708 , dated November $17^{\text {th }}, 2011$. The strategies to consolidate the policy in the state include prevention and control of obesity, domestic violence, engagement of the local population in activities, such as Men's National Day, seminars, elaborations of brochures, etc. According to the plan, there are 2,537,790 men living in the urban areas; another 1,284,047 in the rural areas, and 1,964,780 men between 20 and 59 years in both urban and rural areas (SESPA, 2011).

The epidemiological data enumerated in 2011, for this age bracket indicate the leading occurrences: lesions, poisoning and other external causes totaling 20,325 cases; infectious and verminous diseases with 15,542 occurrences; digestive tract disorders with 12,417 cases. As for psychological suffering, 11,455 men are diagnosed with mental and behavioral disturbances (SESPA, 2011).

In the field of justice, the institution responsible for the education-justice interface is Núcleo Especializado de Atenção ao Homem-NEAH (Nucleus Specialized of Attention to Men) with origin in a partnership between Public Defender Office of the State of Pará and the Ministry of Justice. The philosophy that supports the interventions of NEAH are the guidelines set by the Program of Promotion to Sentences and Alternative Measures. The participation in groups of reflection, in lectures and workshops on domestic violence form a set of alternative measures (NEAH, 2012).

Reasserting what we have said before, interventions in the field of change of posture of man and the couple require the integration of both individuals in activities related o health, education, human rights and social justice. We should remember that the Convention of Belém do Pará (1994) is one of the bases to understand violence against women as a public health issue which affects everyone regardless of race ethnicity, socio economic level and age. National and international researches on the issue indicate its high prevalence and qualification as a violence of human rights and a hindrance for the achievement of gender equality (Brasil, 2006).

In turn, Lyra, Medrado, Barreto \& Azevedo (2012) state that the report of the Conference on Population and Development of Cairo held in 1994, recommends working with men. However, "men surge in the utilitarian perspective, as a benefit to the life condition of women and children, immersed in an argument of responsibility and obligation. We are far from that, but we can still think of them as subjects of rights or objects of policies” (p.

\footnotetext{
${ }^{5}$ Groups of 10 voluntary participants, who meet every week for16 sessions, after clinical interview done with each spouse.

${ }^{6}$ The research interlocutors were granted a scholarship during their military training which corresponds to two monthly minimum wages.
} 
9). Pinheiro \& Couto (2012: p. 50) remark that "the implementation of PNAISH legitimizes and expands the academic debate about the relation men and health-care and, opens space for reflection and proposition on how to provide them some assistance".

On the conjugal violence situation, Beiras, Ried \& Toneli (2011) did some analyses of policies of intervention programs carried out in Latin America and Portugual. From this approach we started an analysis of the masculine social representations.

\section{Masculinities}

In the international discussion Fonseca (1998), bases his position on the North American context of the 20th Century, and presents his classifying perspective: 1) The essentialists theories, with emphasis on the conceptions on sexuality elaborated by Kinsey, Masters and e Johnson; the psychoanalytical investigations on gender done by Chodorov which explores the object relations and the process of separation between mothers and their boys; 2) theories on social roles, in the functional arena devised by the Sociologist Parsons; and the Foucauldian model represented by Joseph Pleck; 3) costructionism, developing an epistemology that stressed the ideological character of the male domination; 4) the theories of gender, emphasizing the cultural variations, contents, activities, discourses, experiences as qualifying dimensions of manhood.

Four theoretical lines - essentialist, positivist, normative and semiotics - where different models, universal and stable characteristics and identity symbols of masculinity, as well the common aspect present in all beacons, demarcate an arbitrary exercise of power sustained by rationality and by hegemony of one type of man: the white Anglo Saxon. These are the references analyzed by Connell. Following, this author considered masculinity as a position in relation to genders (Connell, 1995).

In the Brazilian scenario, the debate presents the subjectivity, the definition of masculinity, sexuality, the changes in gender relations, the understanding of masculine practices, paternity, the references for the youth and more recently health as some of the researchers' concerns. Grossi (2004) in a literature revision on masculinity challenges the qualities and images assigned to men when defining masculinity. He assures that in Brazil the gender identity mark is formed by sexual activity, while in Europe and the United States it is formed by heterosexuality. This author emphasizes that what really matters most for the Brazilian man, during sexual intercourse, is penetration and not his partner. In Pimentel (2011) I stated that, it seems to me that the most important thing in this activity is the maintenance of a social image as a "stallion, virile" and self-image as potent where the reflection about games of power and ideology imprisons men by the money-talks dimension.

The researches show how to conceive the masculine condition that may be called modern matrix. In the $21^{\text {st }}$ Century, the heterosexual man begins to associate the beauty issue to identity, which had been little emphasized during the $20^{\text {th }}$ Century, during the construction of the masculine representation. Parallel to characteristics of provider, of virile male, aggressive man, the investigations point out the thesis of the male condition "crisis", concerning ruptures on the exercise of patriarchal power, of the civil institutions, with particular reference to the family and school; at work, through employability and the exchange made with women of public for private space; a more present paternity; in a more flowing sexuality and affectivity (Pimentel, 2011).

The social representations of masculinity and femininity that circulate socially are elaborated subjectively, sometimes including internal references to influences of unhealthy family models where conjugal violence is emphasized.

In the international scenario, the first programs to face violence against woman were elaborated in Canada and the USA in the 80's: Among them: Counseling \& Education to Stop Domestic Violence e the Duluth Model, Domestic Abuse Intervention Project. In Brazil, in order to help understand and learn about the dynamics that domestic violence undertakes in the relation between couples and families, it was created Rede Brasileira de Pesquisas sobre Violência, saúde, Gênero e Masculinidades_VISAGEM (Brazilian Network of Research on Violence, Gender and Masculinity_VISAGEM) (Lima \& Buchele, 2011).

On the punctual actions, the logic of prison that removes from the house, without emphasizing the reconceptualization of perceptions and experiences with domestic violence learning is a strong connection in the ideology of some social movements of women/feminists. As for Brazilian programs and public policies for recuperation, reeducation and psychotherapy, the literature has shown low interventions, among them: a Campanha do Laço Branco (White Bond Campaign), Siga Bem Mulher (Women do Well Project), Centro Especial de Orientação à 
Mulher-CEOM (Special Center for Woman Guidance) from São Gonçalo/RJ, Centro de Apoio a Famílias (Center for Family Support) in situation of violence, and Casa Abrigo de Santa Catarina (Shelter Home of Santa Catarina) (Lima \& Buchele, 2011).

In 2014, the Department of Sociology of the School of Philosophy, Letters and Human Sciences of the University of São Paulo arranged the Seminar on Feminism and Masculinity to address domestic violence and proposals of intervention carried out in Brazil by various groups working to confront and reduce women's death.

As a result of the event Eva Alterman Blay composed a book from which we separated a text produced by Acosta and Bronz (2014). The authors make a retrospective emphasizing the methodological aspect of endeavors with men under situation of violence. They stress the importance of systemic approach and the complexity of the phenomenon, and overall they highlight the forms of addressing men: "In the beginning they were called aggressors, with ideas associated to the area of gender, they became "authors of violence against women", changing to "men under situation of violence with their intimate female partners" (pp. 141-142).

We understand that the language transmits values and ideologies through polysemic meanings, thus the renaming of men is a form to overcome essentializing concepts and the binary logic present in the understanding of genders, as well as considering the context and interactions in the original context of domestic violence.

\section{Methodology}

This is about a qualitative research in clinical psychology of gestalt phenomenological orientation in interface with feminist studies of gender, masculinity and human rights. According to, Osborne (1990: p. 81),

"Phenomenological research is not intended to test a hypothesis. The aim is to understand a phenomenon by allowing the data to speak for themselves, and by attempting to put aside one's preconceptions as Best one can. The method provides us with descriptions of experience which are then interpreted by the researcher from a particular theoretical perspective."

We did some bibliographical survey to find articles on care, masculinity, violence against women. This procedure was to have a basis to qualify the articulation between theory and the empirical material. To locate the sample, we had the mediation of a Psychologist who is also a police colonel and works in a military police health institution. We took her indication and presented to the Institute General Director and the pedagogical coordinator the research project and were authorized to do the study through a lecture on masculinity crisis to students being trained to become military officers. During our exposition we presented a questionnaire and the research consent form and which after an explanation we had the adhesion of $97 \mathrm{men}$.

The research subjects were between 19 and 30 years old. From the sample, only two interlocutors stated that they had no stable intimate relation. We handed out a 3 integrated parts questionnaire: informant's identification $^{7}$, the partner's/wife's identification; experience ${ }^{8}$ with situations of violence and prevention ${ }^{9}$. In this paper we focus specifically the answers given to define violence and the ideas on how to prevent it.

As for the ethical cares, we subjected the Project to Plataforma Brasil. Since the first contacts with the subjects involved, we respected the procedures provided for on Resolution n 196/96, of the National Health Council/ Ministry of Health which sets forth the research norms involving human beings. The subjects were invited to adhere to the questionnaire receiving information about the project and criteria for their participation in the research. They were shown and informed of the research consent form and received information on the questions regarding the ethics of the research with human beings set forth by the National Health Council. They were assured of the confidentiality of their names and the use of pseudonyms. To be included in the research, the subject had to be between 19 and 50 years old, literate and capable of signing the term of free and clarified consent. The criteria for exclusion considered those below the age of 19; the ones unavailable for the research and the illiterate ones.

For the analysis, the data were organized in terms of descriptive-interpretative theme. We stress the qualitative proprieties found based on the characterization of the examined elements. The results were organized in three axis: definition of violence; recommendations to the female partner, and suggestions to the men. All questionnaires were read and reread to select those common answers to the group, the unique ones to the respondent, and write a synthesis of the material found.

\footnotetext{
${ }^{7}$ The informant's and his partner's pseudonym, age, education and salary.

${ }^{8}$ Childhood experience with violence; self-image; definition of domestic violence.

${ }^{9}$ Suggestion to the partner and other men.
} 


\section{Results and Discussion}

The conceptions of domestic violence mentioned by the interlocutors stress dimensions interconnected that may be combined in two categories: 1) intrasubjective, concerning lack of emotional control; 2) intersubjective, where imposition and disrespect culminate with lack of recognition of the partner during acts of violence. In the same manner as the dynamic of establishment of domestic violence, the lack of control + imposition + disrespect were also recurrent. As mentioned by the interlocutors, conflict that occurs with couples, with most of them beginning with men, who are naturally stronger and use it to impose their will before their female partners; It starts with minor misunderstandings and may reach or not a painful tragedy, but still considered severe.

It attracted our attention during the men's account the perception that there are some stereotypes still present in the conjugal relation, such as the association of physical strength and the centralization of power to the men's "nature".

The percentages for the main identifiers of domestic violence conception are: $47 \%$ for physical aggression and psychology; 11\% for disrespect, 5\% for imposition; 3\% for lack of control, and 34\% for a group of expressions added to the category of violence between couples. We can perceive that, $19 \%$ of the responses can be considered causes, and 81\% consequences; which leads us to consider a need for further reflections, debate and intrapersonal development with the men and the couple to identify factors that motivate domestic violence and procedures to prevent it.

The findings on psychological and physical violence are similar to those found in Lisbon, Portugal , as reported on a research done in 2007 by Matos and Cols (2014), “The most prevalent violence is the psychological one (53.9\%), followed by physical violence (22.6\%) and sexual violence $(19.1 \%)$. The riskiest place is home itself with the husband as the major aggressor (72.7\%)".

In summary, we enhance that psychological domestic violence is meant as disrespect, lack of control and imposition. We have selected some excerpts: lack of emotional control, caused by immaturity in the relationship; anger reflected on the partner; Violent imposition of conditions upon the partner; Inflict the aggressor's subjective limits; of physical or psychological pain within the couple's environment; attempt to impose a certain authority by force; lack of mutual respect concerning the other partner's deficiencies.

When making suggestions for the wives and female partners, the respondents emphasized personal qualities such as; dialogue, patience and calmness, understanding and respect. Self-control and dialogue are means of prevention, the key for everything between couples, paramount to avoid violence, because most serious arguments have their origin in the lack of dialogue between couples.

They have also mentioned the importance of questioning in order to understand the partner's motivation, in order words: always asking the reasons why? Often, violence originates from lack of attention and dialogue; the first step is to sit and talk with the partner advising that his/her attitude is not correct, and if it continues, he/she will be denounced and the relationship terminate whether marriage or not. Communication benefits tolerance, to be more patient and address themes considered disturbing; to have more freedom to express oneself, to give opinions and suggestions during the relationship.

When dialogue was not possible it was suggested that the woman seek legal expertise: in cases of violence to report it to the police. Such conjecture permits us to infer that it is not woman the one responsible to "save the marriage" regardless of her unhappiness and suffering. Thus, the men from the sample indicated: the police should be called at the very first occurrence; do not be inhibited; do not get isolated; do not keep to yourself or hide any violent act against you; first, sit down and talk with your partner, warning that his/her attitude is not correct and that if it continues that you will make a police report and terminate the marriage/stable relationship; try to know the person better and in cases of violence make a threaten with a police report; if you discover during the initial period of your relationship that the partner is violent, move away as fast as possible.

Other procedures equally important for communication were the impulse control, patience and calmness; therefore, female partners should think first before acting and speaking; look for happiness in the partner's pleasure. By not losing control and staying calm it is possible to perceive the partner's emotional state; to think carefully because certain decisions are crucial; do not permit feelings to set over reason; be flexible; be aware for changes; be less aggressive.

An element of facilitation that was stressed is the capacity for empathy, so that the partners may put themselves in the other partner's place before listening, without being humiliated or downgraded.

Some forms of self-control that can be exercised are: never to act violently because the reaction can be vi- 
olence; substantiate your accusations of treason as scientifically as possible, and avoid being taken over by emotions; be controlled in a moment of anger; manage stress though physical activity, dialogue and impulse control; do not stimulate lack of patience for very small reasons. As for dialogue: be attentive toward the partner's emotional state; feel empathy, trust and be trusted; maintain a high level of communication and perceive the partner's level of tolerance.

The quantitative indicators show $37 \%$ for dialogue; $15 \%$ for patience/calmness; $15 \%$ for understanding; $13 \%$ for respect. The fields with fewer incidences, but, that might have a high impact were self-control with $5 \%$ and police report 9\%. Maybe this strategy has not been adhered entirely by men due the symbolic and social consequences caused by a police report, besides demanding responsibility for the setting up of violence in the couple relationship.

In summary, the suggestions can be grouped in a linear scenario, that is, of casual relations between provoked violence and its occurrence; also, on a daily basis of the relationship, it seems that the couple was in a permanent attempt to convince each other than in communication, an action of intensive difficulty, since it requires listening and attention while the partner is talking. Buber (1982: pp. 53-54) alleged that there are three forms of dialogue: "the authentic, when each partner has the intent to establish a live reciprocity; the technical one moved only by objective understanding; and the monologue disguised as dialogue, when the partners talk to themselves".

As for suggestions to both partners, the respondents mentioned timidly the adoption of the perspective of equality, since it has been often recommended as means of prevention of conjugal violence the dialogue + understanding + respect + patience and calmness. The equality of rights is a result of a better understanding of women as the other partner, and not as an object is what we took from the narratives: to perceive that the wife or partner is not an object but someone who is important for one self's personal development, besides the satisfaction provided by a good company; think of women as person and not as a sexual or domestic object.

The quantitative indicators show $23 \%$ for dialogue; $18 \%$ for patience/calmness; $12 \%$ for self-control and understanding respectively. The addition of those indications that do not see women as an object (2\%), equal rights (2\%) and treat the partner well (3\%) is over 7\%, indicating a reduced rate for equality.

The interlocutors also indicate the way for good care requires a mutual effort to recognize alterity and exercise tolerance. The coexistence leads to the daily relationship the existential stories of each individual partner , which requires opening the difference in the forms of understanding the world.

The men who participated of the research proposed that their partners know their emotions and warn that, if the couple is not capable of achieving healthy marital relations that they report and terminate it. And, in the peculiarity of the suggestions to other men we emphasize equal rights, which is different from perceiving women as an object but as a partner who must be treated well

To illustrate these conditions, we have highlighted some excerpts: that he does not use his physical force to impose power; he should understand the relation as a horizontal condition of power between the two partners; man needs to know that his right is similar to that of woman, therefore he should respect the feminine space and reject the use of violent practices to impose his will.

The interlocutors advise other men and couples to practice mutual recognition: first, the couple must love each other and whenever something bad happens they must stay together and overcome such problems, always talk when something is disturbing, but for that they must be open and frank, and finally take of the partner as if it were you; avoid drug consumption; focus anger on the situation and try to solve it rather than direct it toward your partner; discus your problems with a specialist; do not insist on relationships that already had some type of violence and always talk with your female partner.

\section{Final Considerations}

The men who participated of this study not only were pursuing a college degree in public safety but also had some education (complete or incomplete) in human sciences, such as psychology, pedagogy and social sciences. Such profile suggests the importance to aggregate knowledge about patriarchal ideology and matters related to gender, specially the most recent advances in the area of legislation and Science.

We consider that the obtainment of information and change of attitude in relation to its process of subjectivation, to women and gender violence, collaborates with men to establish ruptures on the path to inequalities and psychological suffering. Under this perspective, research has been done by Anderson (2013) in the USA and England to redefine masculinity, aiming the new generation to contribute for the understanding of new forms of 
subjectivation. This author points out that there are, between men, relations based on increasing intimacy and non-sexual physical contact.

In Brazil, according to Acosta (2014) the development of the methodology of group work began in the early 90s, with actions initially carried out as interventions followed by the establishment of partnerships with universities in Rio de Janeiro and non-governmental organizations to carry on research. The author points out that the creation of a working group by the Noos Institute, the Nucleus of gender, health and citizenship around the line of research made it possible the redefinition of the methodology being constructed by the adoption of the systemic theory referential.

Our experience with domestic violence has included the brief psychotherapy as a strategy to break away with stereotyped learnings and psychological processes oriented toward defensive mechanisms that create adjustments, where creativity is absent, but the orientation of introjective and /or confluent norms that impose on men certain behaviors that they do not always agree with, but continue to reflect by force of social pressure coming from several institutions where they have access. Thus, we understand that brief psychotherapy in group has a subsidy potential for suppression of violence between the genders through a dialogue counting on a collection of relevant knowledge which exists between the two situations.

Beiras \& Cantera (2014: p. 39) confirm our perspective of the importance of men who live violence in their intimate relationships to express their emotions, deconstructing myths "in order to enable that they, since childhood, may express their vulnerabilities, sensations, fears, feelings, As means to grant power to other expressions of masculinity, of force and strength".

Monteiro (2012: pp. 25, 31) considers that therapeutic listening contributes for men's self-expression. In the Gestalt-therapy one objective is the awareness increase through unveiling of meanings and motivations that install conjugal violence. This author reminds that "in psychotherapy the way is to make the person feel responsible and conscious of the introjection of "macho" and "patriarchal" values.

The adoption of a tolerant attitude, respect to avoid that aggressions become an usual practice, avoid lies, think in conjunction with the partner, accept the gender differences, preserve a minimum level of privacy in the relationship, act with knowledge, sometimes remain silent, try to know your mistakes, be less selfish, and think about the common good for both of you, be careful and informed on domestic violence, ensure loyalty, be sober, calm, gentle, ask for God's presence in the relationship, education above all, mature personality, treatment against stress, were suggestions given by the interlocutors in the research. We can observe in the propositions a mix of patriarchal paradigm that focuses on fissures in the statistical narratives; however, there is still a lot to do, especially on the perspective of prevention in public health, mainly in primary care.

Brief psychotherapy and the group configure form and place of re-elaboration and questioning of patriarchal culture, where identity and difference between men and women is thought in its non-essentialist complexity. We agree with Silva and Cols (2013) that psychological suffering has multiple expressions, thus the acceptance and listening by the man, the woman, and the couple favors the despatialization and not imposition by man to participate of groups of education as an alternative to imprisonment. Thus, it is possible to understand and organize brief psychotherapy in a socio political approach focusing on the psychological suffering of the experience with situations of violence articulating the exam of relational nexus between gender and power (Pimentel, 2011a, 2011b, 2014).

\section{References}

Acosta, F., \& Bronz, A. (2014). Desafios para o trabalho com homens em situação de violência com suas parceiras íntimas. In E. A. Blay (Org.), Feminismos e masculinidades: novos caminhos para enfrentar a violência contra a mulher (pp. 139-148). São Paulo: Cultura Acadêmica.

Amatuzzi, M. M. (2001). Por uma psicologia humana. Campinas, SP: Ed. Alínea.

Anderson, E. (2013).Theorizing Masculinities for a New Generation. Revista Canaria de Estudios Ingleses, 66, 25-36.

Arendt, H. (1970/2004). Da Violência. Available on http://bibliotecaclandestina.tumblr.com/

Ayres, J. R. C. M. (2004). Care and Reconstruction in Healthcare Practices. Interface-Comunicação, Saúde, Educação, 8, 73-92.

Beauvoir, S. (1990). O segundo Sexo, Vol. 1. São Paulo: Circulo do Livro S.A.

Beiras, A., \& Cantera, L. M. (2014). Feminismo pós-estruturalista e masculinidades: Contribuições para a intervenção com homens autores de violência contra mulheres. In E. A. Blay (Org.), Feminismos e masculinidades: Novos caminhos para enfrentar a violência contra a mulher (pp. 29-44). São Paulo: Cultura Acadêmica. 
Beiras, A., Ried, R., \& Toneli, M. J. F. (n.d.). Políticas públicas e programas de atendimento: Homens Autores de violência contra a mulher. http://www.cime2011.org/home/panel2/cime2011_P2_AdrianoBeiras_JulianaReid.pdf

Belém do Pará (1994). http://www.cidh.org/Basicos/Portugues/m.Belem.do.Para.htm

Blay, E. A. (Org.) (2014). Feminismos e masculinidades: Novos caminhos para enfrentar a violência contra a mulher. São Paulo: Cultura Acadêmica.

Brasil (2006). Lei Maria da Penha. Lei No. 11.340 de 07 de agosto de 2006. Coíbe a violência doméstica e familiar contra a Mulher. Secretaria Especial de Políticas para as Mulheres. Presidência da República.

Brasil, Ministério da Saúde. (2008). Política Nacional de Atenção integral à saúde do homem: Princípios e diretrizes. Brasília/DF: Ministério da Saúde, Secretaria de atenção à saúde, Departamento de ações programáticas estratégicas.

Buber, M. (1982). Do diálogo e do dialógico. São Paulo: Ed Perspectiva.

Connell, R. (1995). Políticas de masculinidade. Educação e Realidade, 20, 156-206.

de Albuquerque, F. P. (2012). Agravos à saúde mental dos homens envolvidos em situação de violência. Dissertation, São Paulo: Medical School of USP, Preventive Medicibne Program.

Dejours, C., Abdouchelli, E., \& Jayet, C. (1994). Psicodinâmica do trabalho: Contribuições da escola dejouriana à analise da relação prazer, sofrimento e trabalho. SP: Atlas.

Figueiredo, R., McBritto, M., \& Peixoto, M. (2012). Promoção de Saúde Integral e Abordagem de Gênero como Estratégia de Ação em Saúde Sexual e Reprodutiva de Homens. Boletim do Instituto de Saúde, BIS, Volume 14, No. 1, Agosto.

Fonseca, A. J. M. S. da. (1998). Identidade Masculina segundo Robert Bly. Dissertação de Mestrado, Lisboa: Universidade Aberta, $176 \mathrm{p}$.

Gold, E., \& Zahn, S. (2014). A necessidade de pesquisa em gestalt-terapia. In P. Brownell (Ed.), Manual de teoria, pesquisa e prática em Gestalt-terapia. Tradução de Maria Oneide Willey (pp. 43-54). Petrópolis, RJ: Vozes.

Grossi, M. P. (2004). Masculinidades: Uma Revisão Teórica. Antropologia em primeira mão (pp. 5-37). Florianópolis: Universidade Federal de Santa Catarina.

Holanda, A. F. (2014). Fenomenologia e humanismo: Reflexões necessárias. Curitiba: Juruá.

Japiassu, H. (1982). Introdução à epistemologia da psicologia. Rio de Janeiro: Imago.

Keen, E. (1979). Introdução à psicologia fenomenológica. Rio de janeiro: Interamericana.

Lima, D. C. (2011). Fátima Büchele Revisão crítica sobre o atendimento a homens autores de violência doméstica e familiar contra as mulheres. Physis Revista de Saúde Coletiva, Rio de Janeiro, 21, 721-743.

Lyra, J., Medrado, B., Barreto, A. F., \& Azevedo, M. (2012). Homens e gênero: Desafios na construção de uma agenda de política de saúde. Boletim do Instituto de Saúde, BIS, Volume 14, No. 1, Agosto.

Machado, A., \& Matos, M. (2014). Homens vítimas na intimidade: Análise metodológica dos estudos de prevalência. Psicologia \& Sociedade, 26, 726-736.

Monteiro, F. S. (2012). O papel do psicólogo no atendimento às vitimas e autores de violência domestica. Brasilia: Monografia de conclusão do bacharelado em Psicologia pela Faculdade de Ciências da Educação e Saúde da UniCEUB.

Moura, C. A. R. de. (1989). Crítica da razão na fenomenologia. São Paulo: Nova Stella: Ed da USP.

NEAH (2012). https://www.facebook.com/nucleodohomem

Osborne, J. W. (1990). Some Basic Existential-Phenomenological Research Methodology for Counsellors. Canadian Journal of Counselling, 24, 79-91.

Pimentel, A. (2003). Psicodiagnóstico em Gestalt-terapia. São Paulo: Summus.

Pimentel, A. (2011a). Violência psicológica nas relações conjugais: Pesquisa e intervenção clínica. São Paulo: Summus.

Pimentel, A. (2011b). Interrogar masculinidades em Belém do Pará. Contextos Clínicos, 4, 18-27.

Pimentel, A. (2014). Homens e mulheres em conflito: Um estudo acerca da violência conjugal a partir da psicoterapia na atenção básica de saúde. Fundação Amazônia Paraense de Amparo à Pesquisa-FAPESPA—edital 008/2014, violência e segurança pública, DOE No. 32.652 de 29/05/2014.

Pinheiro, T. F., Couto, M. T., \& da Silva, G. S. N. (2012). Homens e cuidado: Construções de masculinidades na saude pública brasileira. Psicología, Conocimiento y Sociedad, 2, 177-195.

Ricoeur, P. (1988). Interpretação e Ideologias. Rio de janeiro: F. Alves.

Safra, G., Dunker, C., Priszkulnik, L., Debieux, M., \& Migliavacca, E. M. (2009). Ética e violência: O problema da vulnerabilidade psíquica. Memorandum, 16, 8-18. http://www.fafich.ufmg.br/ memorandum/a16/safraetalii01.pdf

Santos, A. M. C. C. (2009). Articular saúde mental e relações de gênero: Dar vozes aos sujeitos silenciados. Ciência \& Saúde Coletiva, 14, 1177-1182. http://dx.doi.org/10.1590/s1413-81232009000400023 
SESPA (2011). Coordenadoria de Saúde do Homem. Plano de ação, portaria 2.708, de 17/11/ 2011.

Silva, C. R. S. da., Matos, F. V. de., Silveira, R. A., \& Barbosa, I. A. (2013). Sofrimento psíquico em mulheres brasileiras: Uma revisão integrativa. EF Deportes.com, Revista Digital, Buenos Aires, Año 18, No. 184, Septiembre. http://www.efdeportes.com/ 